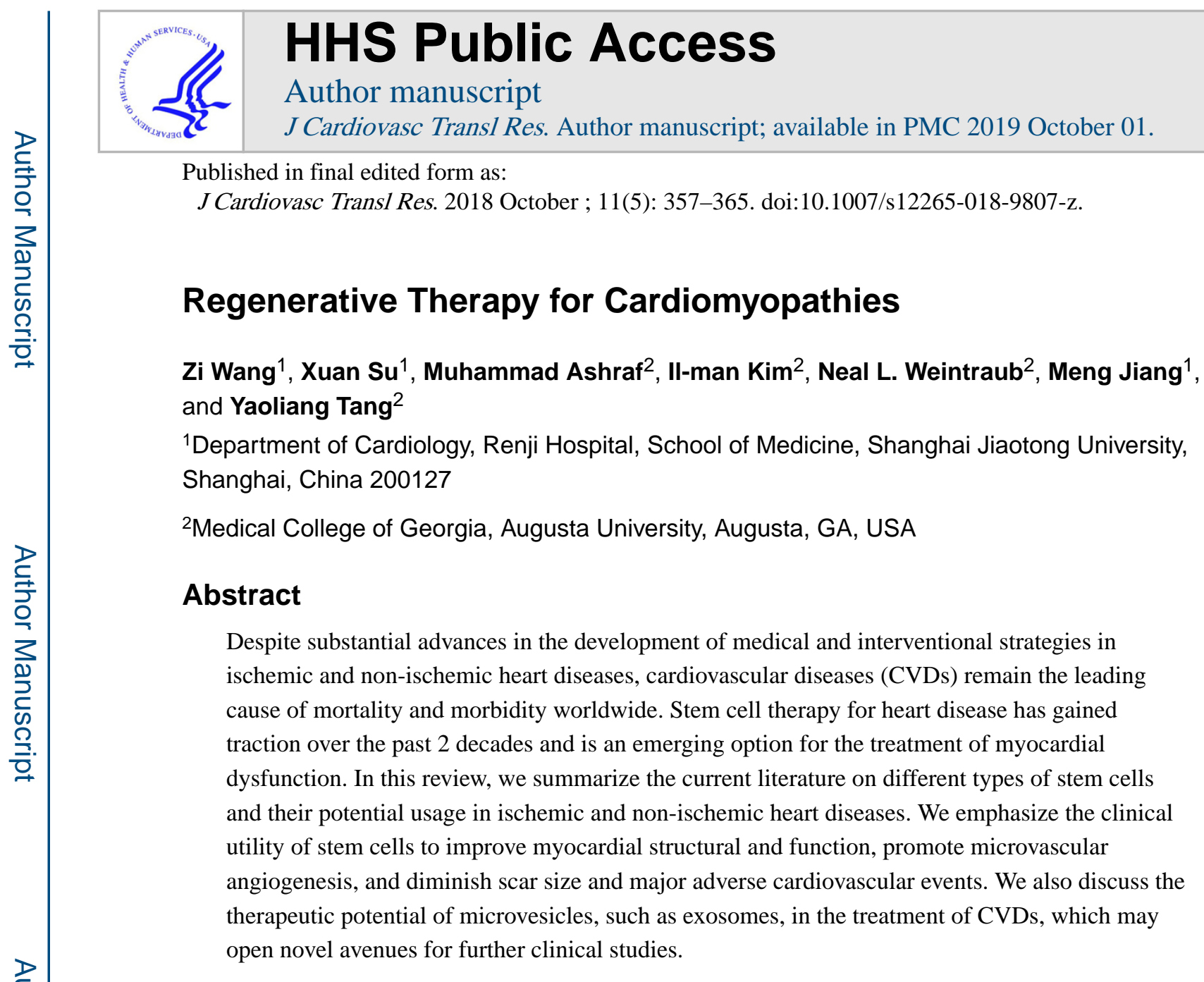

\title{
Introduction
}

Cardiovascular diseases (CVDs) account for approximately $30 \%$ of global mortality, making them the leading cause of mortality worldwide (1). The histological damage associated with scar tissue and the irreversible loss of cardiomyocytes eventually leads to functional depression-heart failure (HF) (1)- and predisposes to malignant ventricular arrhythmias. Despite advances in medical and interventional therapies, none of the current clinical strategies are capable of restoring the loss of viable myocardial tissues (2). The adult heart innately lacks recuperative capacity, which ultimately limits the potential of conventional therapies (3). Heart transplantation can be utilized as a last resort to treat end-stage chronic $\mathrm{HF}$, but the approach is expensive and candidacy is limited by common comorbidities and an insufficient supply of donor organs (3).

\footnotetext{
Correspondence to: Meng Jiang, Professor, Department of Cardiology, Renji Hospital, School of Medicine, Shanghai Jiaotong University, Shanghai, China; 160, Pujian Road, Shanghai, China, 200127. Tel: 086-21-58752345-2445, Fax: 086-21-63574697, jiangmeng0919@163.com.

Yaoliang Tang MD, PH.D, FAHA, Professor of Medicine, Vascular Biology Center, Medical College of Georgia at Augusta University, Augusta, GA 30912, USA, Tel: (706)721-8467, yaotang@ augusta.edu

Compliance with Ethical Standards:

Conflict of Interest:

All authors declares that he/she has no conflict of interest.

This article does not contain any studies with human participants performed by any of the authors.
} 
The basic properties of stem cells are self-renewing capacity and pluripotency, i.e., the potential to differentiate into various functional cell types, such as cardiomyocytes (4), endothelial cells (5) or smooth muscle cells (6). Stem cell therapy for heart disease has gained extensive attention over the past 2 decades and has become a new option for the treatment of the damaged myocardial tissue. The rationale of stem cell therapy is that infused stem cells might contribute to the regeneration of injured cardiac tissues, thereby restoring myocardial contractility and perfusion and improving heart function, exercise capacity, etc. $(7,8)$. Variable types of stem cells have been investigated as promising therapeutic agents, including multipotent stem cells, embryonic stem cells (ESCs), mesenchymal stem cells (MSCs), induced pluripotent stem cells (iPSC), hematopoietic stem cells (HSCs), endothelial progenitor cells (EPCs), cardiac stem cells (CSCs), and bone marrow mononuclear cells (BMMNCs). A number of small scale clinical trials have demonstrated mild to moderate benefit in restoring left ventricular ejection fraction (LVEF) in patients with $\operatorname{HF}(9,10)$. However, the clinical use of stem cells in CVDs is hampered by the incomplete understanding of cardiac tissue repair process, limited differentiation of stem cells into host cell types (11), and constrained therapeutic effects and cell viability under the harsh environment of damaged heart tissue (12).

In this review, we summarize the current literature on different types of stem cells and their potential usage in ischemic and non-ischemic heart diseases. Emphasis will be put on the clinical utility of stem cells on myocardial structural and functional change, microvascular angiogenesis, scar size and major adverse cardiovascular events. We will also consider the evolving therapeutic potential of microvesicles, such as exosomes, in the treatment of CVDs, which may open novel avenues for further clinical studies.

\section{Stem cell therapy for ischemic cardiomyopathy}

The loss of viable myocardial tissues, inadequate perfusion leading to ischemia, and subsequent tissue remodeling are the key issues in ischemic cardiomyopathy. Stem cellbased therapy has been demonstrated to have the capability of cardiac tissue repair in basic research studies $(2,13)$. Clinical trials have traditionally focused on the ability of stem cells to improve cardiac function, remodeling, and exercise capacity. Contemporary research is focused on timing of stem cell therapy to optimally salvage the area at risk and assessing the benefits of stem cell therapy on scar size, microvascular obstruction and intramuscular hemorrhage.

\section{Various types of stem cells}

Different kinds of stem cells have their advantages in the treatment of ischemic cardiomyopathy (ICM). In trials focused on this area, bone marrow-derived stem cells were commonly applied in an attempt to regenerate the infarcted myocardium using multipotent stem cells, MSCs or BMMNCs. The majority of clinical trials successfully demonstrated their safety, feasibility and effectiveness in improving LVEF to a mild-to-moderate extent (commonly 3-5\% LVEF increase). Amelioration of left ventricular remodeling and infarct size reduction was also observed (14-16). EPCs were also extensively investigated over the past 2 decades with regard to repairing damaged heart and found to improve cardiac systolic 
function post-myocardial infarction. In addition, ESC-derived cardiomyocytes transplanted into the injured heart were suggested to contract synchronously with host cardiomyocytes and protect against arrhythmias, and to enhance the ejection fraction (17). Multiple preclinical studies reported this phenomenon, despite the controversy surrounding the capability of EPCs to promote angiogenesis $(18,19)$. Additionally, CSCs, isolated from heart tissue, have been observed in a phase 1 clinical trial (Stem Cell Infusion in Patients with Ischemic cardiOmyopathy [SCIPIO]) for the treatment of heart failure resulting from ischemic heart disease to preserve heart function, reduce infarct size and attenuate adverse myocardial remodeling (9). Recently, iPSCs have emerged as a promising cell source in cardiac regeneration (20) associated with their robust differentiation into cardiomyocytes coupled with the low risk of immune rejection (21). Currently, stem cell therapy is considered to be an alternative clinical approach with the possibility to reduce the incidence of death, recurrent MI, ventricular arrhythmia, and cerebrovascular accident during followup in the first 12 months (22).

\section{Genetic modifications of stem cells}

Genetic modifications of stem cells has the potential to enhance efficiency of cell therapy. Overexpression of cytoprotective genes, a strategy directed towards increasing the survival of transplanted cells, has been applied to different types of stem cells, especially MSCs (13). Researchers reported that upregulated expression of Akt in transplanted MSCs blunted ischemic-induced cardiomyocyte injury, collagen deposition, inflammation, infarction size and ventricular remodeling (23-25). Moreover, Aonuma et al. demonstrated that APE1 overexpression in Cardiac progenitor cells (CPCs) improved LVEF (APE1-CPC: 11.2 $\pm 4.0 \%$, control-CPC: $3.1 \pm 6.7 \%$ vs control-medium: $23.5 \pm 5.3 \%$; $\mathrm{p}<0.01$ ) while reducing cardiac inflammation and fibrosis in the ischemic heart through TAK1-NF- $\mathrm{kB}$ pathway activation, serving as a novel strategy to improve cardiac cell therapy (26).

Overexpression of other cytoprotective proteins, such as heme oxygenase- 1 and silent mating type information regulation 2 homolog 1 , as well as pro-angiogenic factors, was also demonstrated to produce therapeutic benefit. Continuous advances of techniques for delivering the target genes will likely further improve the outcome of therapy with the genetically engineered stem cells.

\section{Combined multi-cell therapy}

Combining different types of stem cells has been hypothesized to lead to superior outcome in eliciting cardiac repair. Groups led by Karantalis have separately reported that injection of MSCs and CSCs together could achieve greater scar size reduction (MSCs: $-44.1 \pm 6.8 \%$; CSC combined with MSC $-37.2 \pm 5.4 \%$; control $-12.9 \pm 4.2 \%$; $p<0.0001)$ (27) and William's demonstrated that combining MSCs and CSCs achieved better left ventricular chamber compliance (end-diastolic pressure-volume relationship; P work and dP/dtmax; $\mathrm{P}<0.05$ ) than either cell therapy alone in swine models, establishing the safety of autologous cell combination strategies (28). Also, Avolio et al. showed that combinational therapy with human saphenous vein-derived pericytes and cardiac stem cells via intramyocardial delivery potentiated cardiac repair in a myocardial infarction model (29). Furthermore, CardioChimeras formed by fusion of CPCs and MSCs exhibited enhanced heart reparative 
capability compared with individual stem cells or combined cell injection, indicating CardioChimeras are a novel cell therapy that might improve on combinational cell approaches to support myocardial regeneration (30). These promising results suggest that combining multitype stem cells could enhance therapeutic efficacy through cell-cell complementary and synergistic effects.

\section{Effect of stem cells on improving exercise capacity}

Exercise capacity is a comprehensive and reproducible physiological endpoint to assess cardiovascular function (31) which correlates closely with the severity of chronic ischemic heart failure. The most widely reported parameters are exercise time and walking distance. Reduced exercise time and peak $\mathrm{O}_{2}$ uptake are powerful markers of worse prognosis in chronic heart failure patients $(32,33)$. In patients with post-infarct heart failure, intracoronary infusion of bone marrow-derived progenitor cells produced a trend towards improved exercise time by $16.8 \mathrm{~s}(\mathrm{p}=0.073)$ at 3 months' follow-up compared with baseline (34). A systematic review of stem cell therapy in patients with acute myocardial infarction reported improvements in diastolic function and exercise capacity (14.29-minute increase in exercise time), and a clinically significant decrease in the ventilation/ $\mathrm{CO}_{2}$ production $\left(\mathrm{VE} / \mathrm{VCO}_{2}\right.$ slope) at 1 year of follow-up) (8).

\section{Effects of stem cells on left ventricular remodeling}

ESCs, MSCs, BMMNCs, and iPSCs are considered to be promising therapeutic candidate stem cells given their self-renewal capacity and potential to differentiate into multiple cell types, including cardiomyocytes (35-38). The administration of these stem cells has resulted in improvements in cardiac systolic and diastolic function and attenuation of left ventricular remodeling in animal studies and in humans $(39,40)$. Strauer et al. carried out the first clinical trial of BMMNCs in AMI in 2002, demonstrating that BMMNCs were safe and effective at improving global and regional left ventricular dysfunction and myocardial perfusion (41). Manginas et al. observed that intracoronary administration of CD133+ or CD34+ cells into post-infarction zones with non-viable myocardium produced a sustained improvement in regional perfusion and a decrease in LV end-diastolic and end-systolic volumes ( $\mathrm{P}=0.008$ and $\mathrm{P}=0.002$, respectively) (42). MSCs, which have the potential to differentiate into a variety of cell types such as chondrocytes, adipocytes, and osteocytes, tendons, as well as cardiomyocyte-like cells, vascular smooth muscle cells and endotheliallike cells, may be particularly effective at reducing myocardial remodeling. Infusion of autologous/allogeneic MSCs in heart failure patients not only prevented ventricular remodeling but also improved the functional capacity, 6-minute walk test, exercise peak $\mathrm{VO}_{2}$, Minnesota Living with Heart Failure Questionnaire, and New York Heart Association classification (10). Finally, BMMNCs and CSCs were consistently suggested to curtail LV dysfunction and vascular remodeling while promoting cardiac tissue regeneration (43-45).

\section{Effects of stem cells on angiogenesis, scar size, microvascular obstruction and intramuscular hemorrhage}

Favorable effects of stem cells on perfusion and myocardial blood flow have been reported in a number of trials of cell therapy (46-48). Enhanced myocardial angiogenesis surrounding infarcted myocardium was detected after administration of CD133+ bone 
marrow cells into patients with ischemic cardiomyopathy treated with coronary artery bypass grafting $(\mathrm{CABG})(44)$. Also, Tang et al. showed that intravenously infused c-kit ${ }^{+}$ CSCs stimulated angiogenesis and improved LV function (21). EPCs derived from bone marrow were reported to mobilize into circulation and home toward ischemic regions, where they participate in neovascularization of the injured tissue in a paracrine manner (49).

As for scar size and microvascular obstruction (MVO), Meneveau et al. reported that presence of endothelial colony-forming cells was associated with reduced infarct size (12.8 $\pm 24 \%)$ and MVO $(3.2 \pm 5 \%)$ at 6 months post infarction (50). Moreover, transplanted stem cells have been reported to reside in para-infarction sites, in association with reduced MVO and preservation of microvascular integrity (51). The change in MVO predicted improvement in LVEF in the randomized, placebo-controlled double-blind SCAMI trial; improvement in LVEF up to 3 years was higher in BMC-treated patients without MVO compared with those with MVO (52). On the other hand, some types of stem cells, such as MSC, have innate procoagulant activity and potentially could aggravate microvascular obstruction following intracoronary delivery $(53,54)$. Heparin, which can reduce MSCassociated thrombosis, was reported to ameliorate MVO associated with MSC therapy (55).

\section{Effects of stem cells on major adverse cardiovascular events}

Major adverse cardiovascular events (MACEs), such as all-cause death, heart failure, myocardial re-infarction, requirement for re-operation, and arrhythmia, are robust outcome measures in patients treated with stem cells. Some systematic reviews and clinical trials have shown that the incidence of MACEs was lower in patients with AMI subjected to selected bone marrow-derived stem cell therapy compared with controls, with a trend toward reduced incidences of heart failure and arrhythmia, albeit not statistically significant $(56,57)$. Conversely, in a meta-analysis of individual patient data from randomized trials in patients with recent AMI, Gyongyosi M. et al. reported that cell therapy did not reduce key MACEs [adverse cardiac and cerebrovascular events $(14.0 \%$ versus $16.3 \%, \mathrm{p}=0.289)$, death $(1.4 \%$ versus $2.1 \%, \mathrm{p}=0.499)$, or death/AMI recurrence/stroke $(2.9 \%$ versus $4.7 \%, \mathrm{p}=0.088)]$ in comparison with controls, and the authors concluded that intracoronary cell therapy provided no benefits against MACEs (58). Larger scale trials with longer follow-up terms are called for to resolve this controversy.

Effects of stem cells therapy are summarized in Table $1[(10,14,18-21,35,39-42,50-54$, $56,59-64)]$

\section{Optimal infusion dose and timing}

There has been a gap between basic and clinical research in terms of cell injection timing and dose. Recently, our group has performed a meta-analysis examining the dosage and timing of MSC transplantation in patients with AMI (65). The data suggest that injection of no more than $10^{7}$ MSCs within 1 week after AMI treated with percutaneous coronary intervention might be optimal to improve left ventricular systolic function and prognosis (65). These findings are consistent with randomized trials showing that the most benefit was achieved when administering cell therapy between 4 and 7 days after AMI (16). 


\section{Mechanisms of benefit of stem cells}

Although the transplanted stem cells have been found to be able to differentiate into cardiomyocytes, vascular smooth muscle and endothelial cells, most studies report that the paracrine effects of stem cells represent the dominant mechanism leading to enhanced survival of existing myocytes, recruitment of progenitor cells, reduction of fibrosis and scar formation, and eventually preservation of heart function (66-68). In addition, other mechanisms, such as simulation of native cardiac stem cells (69), immune modulation (70) and inflammatory control $(71,72)$, enhanced cell homing (73), and stimulation of cell-cell communications (70) have also been suggested to contribute to myocardial recovery.

\section{Extracellular vesicles secreted from stem cells}

Notably, it has recently been reported that extracellular vesicles secreted from stem cells may play a major role in repairing and regenerating the damaged myocardium (74-77). Stem cell-derived extracellular vesicles have potent cytoprotective, regenerative, anti-fibrotic and angiogenic properties, and they can enhance cardiomyocyte differentiation (77-79). Exosomes are a type of lipid bilayer extracellular vesicles of $30-150 \mathrm{~nm}$ in size(ExoCarta.org). The major components of Exosomes are lipid entries (about 1,116), proteins entries (about 41,860), mRNA entries (about 4,946), miRNA (about 2,838) from about 286 studies. Long non-coding RNA and CircRNA were discovered in exosomes, which are important mediators of intercellular communication(80). Exosome are released from stem cells during stress or pathological conditions, contain a variety of miRNA and small molecules that can augment endogenous CPC survival, proliferation and function(75). These exosomes are implicated in stem cell survival (81), proliferation, migration (82), and differentiation into cardiomyocyte lineage $(83,84)$. MiRNAs derived from ESCs, EPCs, MSCs, iPSCs, may be involved in the modulation of myocardial regeneration in ischemic heart tissue $(75,85)$. More research is needed to further validate stem cell-derived exosomes as a therapeutic tool in the treatment of CVDs.

\section{Stem cell therapy for non-ischemic cardiomyopathy}

Non-ischemic cardiomyopathy (NICM), studied much less than its ischemic counterpart (86), has supplanted ICM as the leading cause of heart transplantation in adults (87), outlining the necessity of developing alternative therapies for this entity. The majority of clinical studies in this area were from non-ischemic dilated cardiomyopathy (NIDCM) and hypertrophic cardiomyopathy (HCM).

\section{Non-ischemic dilated cardiomyopathy}

Although current therapeutic approaches to NIDCM improve symptoms and prolong life, they are palliative in that they cannot directly address the fundamental problem of the loss of cardiac tissue and function. It is for this reason that stem cells have sparked intense interest, though the evidence for the therapeutic potential of autologous stem cells for NIDCM has been scarce.

In 2009, Fischer-rasokat et al. evaluated for the first time the effects of BMC for the treatment of NIDCM in a clinical trial and demonstrated the safety and feasibility of stem 
cell therapy, which produced a small but significant improvement of LVEF (from $30.2 \pm 10.9 \%$ to $33.4 \pm 11.5 \%$, Pindex (from $1.53 \pm 0.63$ to $1.32 \pm 0.61 \mathrm{mmHg} \cdot \mathrm{s} / \mathrm{cm}, \mathrm{P}=0.002$ ) after 3 months of BMC infusion, and a decrease in $\mathrm{N}$-terminal probrain natriuretic peptide serum levels (from $1610 \pm 993$ to $1473 \pm 1147 \mathrm{pg} / \mathrm{ml}, \mathrm{P}=0.038$ ) after 12 months (88). Recently, the results of a few small-scale randomized trials reported that intracoronary stem cell transplantation might contribute to the improvement of cardiac systolic function, exercise tolerance, and long-term survival without improvement in left ventricular end-diastolic volume (89-91), suggesting that stem cells do not cause any change in the remodeling process but improve myocardial cell function and quality of life measures. However, not all clinical trials demonstrated the same beneficial effects $(92,93)$. More recently, a systematic review addressed this issue and showed that bone marrow-derived stem cell therapy exhibited a significant reduction in mortality rate $(19.7 \%$ in the cell group vs. $27.1 \%$ in the control group; $95 \%$ confidence interval $(\mathrm{CI})-0.16$ to $\left.-0.00, \mathrm{I}^{2}=52 \%, \mathrm{p}=0.04\right)$. Bone marrow-derived stem cell therapy also significantly improved LVEF after mid-term (6-12 months) follow-up ( $3.53 \%$ increase; $95 \%$ CI 0.76 to $\left.6.29, \mathrm{I}^{2}=88 \%, \mathrm{p}=0.01\right)$ but produced no significant benefit in the 6 minutes walking test $(\mathrm{p}=0.18)(94)$.

\section{Hypertrophic cardiomyopathy}

HCM is another genetic NICM with an incidence of 1:500 in general population that is best known for its associated risk of sudden cardiac death in athletes $(95,96)$. Current medications, devices and surgery can significantly improve symptoms, but no specific strategies have been directed towards the underlying disease pathogenesis. Stem cell research may lead to novel approaches in the treatment of $\mathrm{HCM}$, but the field is just now emerging. In 2014, Han et al. developed a patient-specific iPSC-derived cardiomyocytes (iPSC-CMs) model in vitro to evaluate therapeutic benefits of pharmaceutical agents, and demonstrated the potential of using iPSC-CMs for future development of personalized therapeutic strategies (97). At present, however, insufficient data are available to draw solid conclusions regarding the potential for stem cell therapy in HCM.

\section{Limitations and potential risks of stem cell therapy}

Despite the promising aspects of stem cell therapy in CVDs, the associated limitations of cell-infusion therapy must be recognized, indicating the need for proceeding with improvement, for example, the donor cell survival and engraftment are important issues determining the long term beneficial effect of stem cell therapy, over $85 \%$ of donor cells were lost $24 \mathrm{hrs}$ post cell transplantation(98). Immune rejection of iPSCs, difficulty in controlling stem cell behavior in vivo, risks of obstructing the microvessels $(54,99)$, and tumor-like formation (100) are issues that merit particular consideration. For example, stem cells infused immediately after AMI might cause excessive obstruction and dysfunction in the microvascular bed, thereby creating a hostile environment due to inflammation of the myocardium, potentially limiting cell retention and engraftment (101). The potential of stem cell therapy for cardiac repair may be influenced not only by cell dosage but also by patient status, such as the level of baseline ejection fraction, as well as patient's age, gender and diabetic status (102). Therefore, more preclinical and clinical trials are required to 
demonstrate the most suitable therapy strategy depending on the underlying clinical process and individual patient variables.

\section{Future perspective}

In the absence of specific target-oriented therapy, stem cell-based therapy has been emerged as a viable option for cardiac tissue repair in clinical trials. Cell transplantation at the time of acute myocardial infarction or at later times may attenuate severity of cardiac tissue damage and accelerate the regeneration process. Emerging approaches including genetic modification, stem cell-derived exosomes and tissue engineering in combination with biomaterials have been applied to improve the efficacy of stem cell therapy. New clinical markers beyond traditional volumetric indices have transformed quantification of efficacy from primarily morphological to evaluation of tissue characteristics. The combination of clinical evaluation methods has improved our understanding of both the pros and cons of stem cell therapy.

\section{Acknowledgments}

\section{Funding}

This study was supported by the National Natural Science Foundation of China (Nos. 81470391), and the National Natural Science Foundation of China (No. 81528002 to Y.T/Y.H). I. Kim, N.L. Weintraub, and Y. Tang were partially supported by the American Heart Association: GRNT31430008, NIH-AR070029, NIH-HL086555, NIHHL134354, and NIH-HL12425.

\section{References}

1. Sun R, Li X, Liu M, Zeng Y, Chen S, Zhang P. Advances in stem cell therapy for cardiovascular disease (Review). International journal of molecular medicine. 2016; 38(1):23-9. [PubMed: 27220939]

2. Trindade F, Leite-Moreira A, Ferreira-Martins J, Ferreira R, Falcao-Pires I, Vitorino R. Towards the standardization of stem cell therapy studies for ischemic heart diseases: Bridging the gap between animal models and the clinical setting. International journal of cardiology. 2017; 228:465-80. [PubMed: 27870978]

3. Bernstein HS, Srivastava D. Stem cell therapy for cardiac disease. Pediatric research. 2012; 71(4 Pt 2):491-9. [PubMed: 22430385]

4. Moreira ML, da Costa Medeiros P, de Souza SA, Gutfilen B, Rosado-de-Castro PH. In Vivo Tracking of Cell Therapies for Cardiac Diseases with Nuclear Medicine. Stem cells international. 2016; 2016:3140120. [PubMed: 26880951]

5. Silva GV, Litovsky S, Assad JA, Sousa AL, Martin BJ, Vela D, et al. Mesenchymal stem cells differentiate into an endothelial phenotype, enhance vascular density, and improve heart function in a canine chronic ischemia model. Circulation. 2005; 111(2):150-6. [PubMed: 15642764]

6. Nagaya N, Kangawa K, Itoh T, Iwase T, Murakami S, Miyahara Y, et al. Transplantation of mesenchymal stem cells improves cardiac function in a rat model of dilated cardiomyopathy. Circulation. 2005; 112(8):1128-35. [PubMed: 16103243]

7. Fernandes S, Chong JJ, Paige SL, Iwata M, Torok-Storb B, Keller G, et al. Comparison of Human Embryonic Stem Cell-Derived Cardiomyocytes, Cardiovascular Progenitors, and Bone Marrow Mononuclear Cells for Cardiac Repair. Stem cell reports. 2015; 5(5):753-62. [PubMed: 26607951]

8. Jiang M, Mao J, He B. The effect of bone marrow-derived cells on diastolic function and exercise capacity in patients after acute myocardial infarction. Stem cell research. 2012; 9(1):49-57. [PubMed: 22640927] 
9. Bolli R, Chugh AR, D'Amario D, Loughran JH, Stoddard MF, Ikram S, et al. Cardiac stem cells in patients with ischaemic cardiomyopathy (SCIPIO): initial results of a randomised phase 1 trial. Lancet. 2011; 378(9806):1847-57. [PubMed: 22088800]

10. Hare JM, Fishman JE, Gerstenblith G, DiFede Velazquez DL, Zambrano JP, Suncion VY, et al. Comparison of allogeneic vs autologous bone marrow-derived mesenchymal stem cells delivered by transendocardial injection in patients with ischemic cardiomyopathy: the POSEIDON randomized trial. Jama. 2012; 308(22):2369-79. [PubMed: 23117550]

11. Lee CY, Kim R. Therapeutic Potential of Stem Cells Strategy for Cardiovascular Diseases. 2016; 2016:4285938.

12. Geng YJ. Molecular mechanisms for cardiovascular stem cell apoptosis and growth in the hearts with atherosclerotic coronary disease and ischemic heart failure. Annals of the New York Academy of Sciences. 2003; 1010:687-97. [PubMed: 15033813]

13. Yu H, Lu K, Zhu J, Wang J. Stem cell therapy for ischemic heart diseases. British medical bulletin. 2017; 121(1):135-54. [PubMed: 28164211]

14. Shen H, Wang Y, Zhang Z, Yang J, Hu S, Shen Z. Mesenchymal Stem Cells for Cardiac Regenerative Therapy: Optimization of Cell Differentiation Strategy. Stem cells international. 2015; 2015:524756. [PubMed: 26339251]

15. Strauer BE, Brehm M, Zeus T, Gattermann N, Hernandez A, Sorg RV, et al. Intracoronary, human autologous stem cell transplantation for myocardial regeneration following myocardial infarction. Deutsche medizinische Wochenschrift. 2001; 126(34-35):932-8. [PubMed: 11523014]

16. Schachinger V, Erbs S, Elsasser A, Haberbosch W, Hambrecht R, Holschermann H, et al. Intracoronary bone marrow-derived progenitor cells in acute myocardial infarction. The New England journal of medicine. 2006; 355(12):1210-21. [PubMed: 16990384]

17. Shiba Y, Fernandes S, Zhu WZ, Filice D, Muskheli V, Kim J, et al. Human ES-cell-derived cardiomyocytes electrically couple and suppress arrhythmias in injured hearts. Nature. 2012; 489(7415):322-5. [PubMed: 22864415]

18. Jin P, Li T, Li X, Shen X, Zhao Y. Suppression of oxidative stress in endothelial progenitor cells promotes angiogenesis and improves cardiac function following myocardial infarction in diabetic mice. Experimental and therapeutic medicine. 2016; 11(6):2163-70. [PubMed: 27284297]

19. Wu Y, Ip JE, Huang J, Zhang L, Matsushita K, Liew CC, et al. Essential role of ICAM-1/CD18 in mediating EPC recruitment, angiogenesis, and repair to the infarcted myocardium. Circulation research. 2006; 99(3):315-22. [PubMed: 16825578]

20. Kawamura M, Miyagawa S, Fukushima S, Saito A, Miki K, Ito E, et al. Enhanced survival of transplanted human induced pluripotent stem cell-derived cardiomyocytes by the combination of cell sheets with the pedicled omental flap technique in a porcine heart. Circulation. 2013; 128(11 Suppl 1):S87-94. [PubMed: 24030425]

21. Tang YL, Zhu W, Cheng M, Chen L, Zhang J, Sun T, et al. Hypoxic preconditioning enhances the benefit of cardiac progenitor cell therapy for treatment of myocardial infarction by inducing CXCR4 expression. Circulation research. 2009; 104(10):1209-16. [PubMed: 19407239]

22. Afzal MR, Samanta A, Shah ZI, Jeevanantham V, Abdel-Latif A, Zuba-Surma EK, et al. Adult Bone Marrow Cell Therapy for Ischemic Heart Disease: Evidence and Insights From Randomized Controlled Trials. Circulation research. 2015; 117(6):558-75. [PubMed: 26160853]

23. Mangi AA, Noiseux N, Kong D, He H, Rezvani M, Ingwall JS, et al. Mesenchymal stem cells modified with Akt prevent remodeling and restore performance of infarcted hearts. Nature medicine. 2003; 9(9):1195-201.

24. Matsui T, Tao J, del Monte F, Lee KH, Li L, Picard M, et al. Akt activation preserves cardiac function and prevents injury after transient cardiac ischemia in vivo. Circulation. 2001; 104(3): 330-5. [PubMed: 11457753]

25. Huang J, Guo J, Beigi F, Hodgkinson CP, Facundo HT, Zhang Z, et al. HASF is a stem cell paracrine factor that activates PKC epsilon mediated cytoprotection. Journal of molecular and cellular cardiology. 2014; 66:157-64. [PubMed: 24269490]

26. Aonuma T, Takehara N, Maruyama K, Kabara M, Matsuki M, Yamauchi A, et al. ApoptosisResistant Cardiac Progenitor Cells Modified With Apurinic/Apyrimidinic Endonuclease/Redox 
Factor 1 Gene Overexpression Regulate Cardiac Repair After Myocardial Infarction. Stem cells translational medicine. 2016; 5(8):1067-78. [PubMed: 27334489]

27. Karantalis V, Suncion-Loescher VY, Bagno L, Golpanian S, Wolf A, Sanina C, et al. Synergistic Effects of Combined Cell Therapy for Chronic Ischemic Cardiomyopathy. Journal of the American College of Cardiology. 2015; 66(18):1990-9. [PubMed: 26516002]

28. Williams AR, Hatzistergos KE, Addicott B, McCall F, Carvalho D, Suncion V, et al. Enhanced effect of combining human cardiac stem cells and bone marrow mesenchymal stem cells to reduce infarct size and to restore cardiac function after myocardial infarction. Circulation. 2013; 127(2): 213-23. [PubMed: 23224061]

29. Avolio E, Meloni M, Spencer HL, Riu F, Katare R, Mangialardi G, et al. Combined intramyocardial delivery of human pericytes and cardiac stem cells additively improves the healing of mouse infarcted hearts through stimulation of vascular and muscular repair. Circulation research. 2015; 116(10):e81-94. [PubMed: 25801898]

30. Quijada P, Salunga HT, Hariharan N, Cubillo JD, El-Sayed FG, Moshref M, et al. Cardiac Stem Cell Hybrids Enhance Myocardial Repair. Circulation research. 2015; 117(8):695-706. [PubMed: 26228030]

31. Arena R, Myers J, Abella J, Pinkstaff S, Brubaker P, Kitzman D, et al. Defining the optimal prognostic window for cardiopulmonary exercise testing in patients with heart failure. Circulation Heart failure. 2010; 3(3):405-11. [PubMed: 20200329]

32. Balady GJ, Arena R, Sietsema K, Myers J, Coke L, Fletcher GF, et al. Clinician's Guide to cardiopulmonary exercise testing in adults: a scientific statement from the American Heart Association. Circulation. 2010; 122(2):191-225. [PubMed: 20585013]

33. Mancini DM, Eisen H, Kussmaul W, Mull R, Edmunds LH Jr, Wilson JR. Value of peak exercise oxygen consumption for optimal timing of cardiac transplantation in ambulatory patients with heart failure. Circulation. 1991; 83(3):778-86. [PubMed: 1999029]

34. Honold J, Fischer-Rasokat U, Seeger FH, Leistner D, Lotz S, Dimmeler S, et al. Impact of intracoronary reinfusion of bone marrow-derived mononuclear progenitor cells on cardiopulmonary exercise capacity in patients with chronic postinfarction heart failure. Clinical research in cardiology : official journal of the German Cardiac Society. 2013; 102(9):619-25. [PubMed: 23612920]

35. Nir SG, David R, Zaruba M, Franz WM, Itskovitz-Eldor J. Human embryonic stem cells for cardiovascular repair. Cardiovascular research. 2003; 58(2):313-23. [PubMed: 12757866]

36. Wong SS, Bernstein HS. Cardiac regeneration using human embryonic stem cells: producing cells for future therapy. Regenerative medicine. 2010; 5(5):763-75. [PubMed: 20868331]

37. Rajasingh J, Thangavel J, Siddiqui MR, Gomes I, Gao XP, Kishore R, et al. Improvement of cardiac function in mouse myocardial infarction after transplantation of epigenetically-modified bone marrow progenitor cells. PLoS One. 2011; 6(7):e22550. [PubMed: 21799893]

38. Rajasingh J, Bord E, Hamada H, Lambers E, Qin G, Losordo DW, et al. STAT3-dependent mouse embryonic stem cell differentiation into cardiomyocytes: analysis of molecular signaling and therapeutic efficacy of cardiomyocyte precommitted mES transplantation in a mouse model of myocardial infarction. Circulation research. 2007; 101(9):910-8. [PubMed: 17823373]

39. Kawamura M, Miyagawa S, Miki K, Saito A, Fukushima S, Higuchi T, et al. Feasibility, safety, and therapeutic efficacy of human induced pluripotent stem cell-derived cardiomyocyte sheets in a porcine ischemic cardiomyopathy model. Circulation. 2012; 126(11 Suppl 1):S29-37. [PubMed: 22965990]

40. Traverse JH, Henry TD, Pepine CJ, Willerson JT, Zhao DX, Ellis SG, et al. Effect of the use and timing of bone marrow mononuclear cell delivery on left ventricular function after acute myocardial infarction: the TIME randomized trial. Jama. 2012; 308(22):2380-9. [PubMed: 23129008]

41. Strauer BE, Brehm M, Zeus T, Kostering M, Hernandez A, Sorg RV, et al. Repair of infarcted myocardium by autologous intracoronary mononuclear bone marrow cell transplantation in humans. Circulation. 2002; 106(15):1913-8. [PubMed: 12370212]

42. Manginas A, Goussetis E, Koutelou M, Karatasakis G, Peristeri I, Theodorakos A, et al. Pilot study to evaluate the safety and feasibility of intracoronary CD133(+) and CD133(-) CD34(+) cell 
therapy in patients with nonviable anterior myocardial infarction. Catheterization and cardiovascular interventions : official journal of the Society for Cardiac Angiography \& Interventions. 2007; 69(6):773-81. [PubMed: 17394248]

43. Orlic D, Kajstura J, Chimenti S, Jakoniuk I, Anderson SM, Li B, et al. Bone marrow cells regenerate infarcted myocardium. Nature. 2001; 410(6829):701-5. [PubMed: 11287958]

44. Stamm C, Kleine HD, Choi YH, Dunkelmann S, Lauffs JA, Lorenzen B, et al. Intramyocardial delivery of CD133+ bone marrow cells and coronary artery bypass grafting for chronic ischemic heart disease: safety and efficacy studies. The Journal of thoracic and cardiovascular surgery. 2007; 133(3):717-25. [PubMed: 17320570]

45. Lader J, Stachel M, Bu L. Cardiac stem cells for myocardial regeneration: promising but not ready for prime time. Current opinion in biotechnology. 2017; 47:30-5. [PubMed: 28591641]

46. Gao LR, Chen Y, Zhang NK, Yang XL, Liu HL, Wang ZG, et al. Intracoronary infusion of Wharton's jelly-derived mesenchymal stem cells in acute myocardial infarction: double-blind, randomized controlled trial. BMC medicine. 2015; 13:162. [PubMed: 26162993]

47. Amado LC, Saliaris AP, Schuleri KH, St John M, Xie JS, Cattaneo S, et al. Cardiac repair with intramyocardial injection of allogeneic mesenchymal stem cells after myocardial infarction. Proceedings of the National Academy of Sciences of the United States of America. 2005; 102(32): 11474-9. [PubMed: 16061805]

48. Quevedo HC, Hatzistergos KE, Oskouei BN, Feigenbaum GS, Rodriguez JE, Valdes D, et al. Allogeneic mesenchymal stem cells restore cardiac function in chronic ischemic cardiomyopathy via trilineage differentiating capacity. Proceedings of the National Academy of Sciences of the United States of America. 2009; 106(33):14022-7. [PubMed: 19666564]

49. Goretti E, Wagner DR, Devaux Y. Role of MicroRNAs in Endothelial Progenitor Cells: Implication for Cardiac Repair. Journal of stem cells. 2014; 9(2):107-15. [PubMed: 25158159]

50. Meneveau N, Deschaseaux F, Seronde MF, Chopard R, Schiele F, Jehl J, et al. Presence of endothelial colony-forming cells is associated with reduced microvascular obstruction limiting infarct size and left ventricular remodelling in patients with acute myocardial infarction. Basic research in cardiology. 2011; 106(6):1397-410. [PubMed: 21904841]

51. Kanazawa H, Tseliou E, Malliaras K, Yee K, Dawkins JF, De Couto G, et al. Cellular postconditioning: allogeneic cardiosphere-derived cells reduce infarct size and attenuate microvascular obstruction when administered after reperfusion in pigs with acute myocardial infarction. Circulation Heart failure. 2015; 8(2):322-32. [PubMed: 25587096]

52. Wohrle J, von Scheidt F, Schauwecker P, Wiesneth M, Markovic S, Schrezenmeier H, et al. Impact of cell number and microvascular obstruction in patients with bone-marrow derived cell therapy: final results from the randomized, double-blind, placebo controlled intracoronary Stem Cell therapy in patients with Acute Myocardial Infarction (SCAMI) trial. Clinical research in cardiology : official journal of the German Cardiac Society. 2013; 102(10):765-70. [PubMed: 23896972]

53. Porto I, De Maria GL, Leone AM, Dato I, D’Amario D, Burzotta F, et al. Endothelial progenitor cells, microvascular obstruction, and left ventricular remodeling in patients with ST elevation myocardial infarction undergoing primary percutaneous coronary intervention. The American journal of cardiology. 2013; 112(6):782-91. [PubMed: 23746481]

54. Grieve SM, Bhindi R, Seow J, Doyle A, Turner AJ, Tomka J, et al. Microvascular obstruction by intracoronary delivery of mesenchymal stem cells and quantification of resulting myocardial infarction by cardiac magnetic resonance. Circulation Heart failure. 2010; 3(3):e5-6. [PubMed: 20484192]

55. Gleeson BM, Martin K, Ali MT, Kumar AH, Pillai MG, Kumar SP, et al. Bone Marrow-Derived Mesenchymal Stem Cells Have Innate Procoagulant Activity and Cause Microvascular Obstruction Following Intracoronary Delivery: Amelioration by Antithrombin Therapy. Stem cells (Dayton, Ohio). 2015; 33(9):2726-37.

56. Liu B, Duan CY, Luo CF, Ou CW, Sun K, Wu ZY, et al. Effectiveness and safety of selected bone marrow stem cells on left ventricular function in patients with acute myocardial infarction: a metaanalysis of randomized controlled trials. International journal of cardiology. 2014; 177(3):764-70. [PubMed: 25465825] 
57. Yu CW, Choi SC, Hong SJ, Choi JH, Park CY, Kim JH, et al. Cardiovascular event rates in patients with ST-elevation myocardial infarction were lower with early increases in mobilization of Oct4(high)Nanog(high) stem cells into the peripheral circulation during a 4-year follow-up. International journal of cardiology. 2013; 168(3):2533-9. [PubMed: 23602281]

58. Gyongyosi M, Wojakowski W, Lemarchand P, Lunde K, Tendera M, Bartunek J, et al. MetaAnalysis of Cell-based CaRdiac stUdiEs (ACCRUE) in patients with acute myocardial infarction based on individual patient data. Circulation research. 2015; 116(8):1346-60. [PubMed: 25700037]

59. Nasseri BA, Ebell W, Dandel M, Kukucka M, Gebker R, Doltra A, et al. Autologous CD133+ bone marrow cells and bypass grafting for regeneration of ischaemic myocardium: the Cardio133 trial. European heart journal. 2014; 35(19):1263-74. [PubMed: 24497345]

60. Heldman AW, DiFede DL, Fishman JE, Zambrano JP, Trachtenberg BH, Karantalis V, et al. Transendocardial mesenchymal stem cells and mononuclear bone marrow cells for ischemic cardiomyopathy: the TAC-HFT randomized trial. Jama. 2014; 311(1):62-73. [PubMed: 24247587]

61. Honold J, DeRosa S, Spyridopoulos I, Fischer-Rasokat U, Seeger FH, Leistner D, et al. Comparison of the Seattle heart failure model and cardiopulmonary exercise capacity for prediction of death in patients with chronic ischemic heart failure and intracoronary progenitor cell application. Clinical cardiology. 2013; 36(3):153-9. [PubMed: 23377956]

62. Xiong Q, Ye L, Zhang P, Lepley M, Swingen C, Zhang L, et al. Bioenergetic and functional consequences of cellular therapy: activation of endogenous cardiovascular progenitor cells. Circulation research. 2012; 111(4):455-68. [PubMed: 22723295]

63. Bartunek J, Behfar A, Dolatabadi D, Vanderheyden M, Ostojic M, Dens J, et al. Cardiopoietic stem cell therapy in heart failure: the C-CURE (Cardiopoietic stem Cell therapy in heart failURE) multicenter randomized trial with lineage-specified biologics. Journal of the American College of Cardiology. 2013; 61(23):2329-38. [PubMed: 23583246]

64. Takahashi K, Yamanaka S. Induction of pluripotent stem cells from mouse embryonic and adult fibroblast cultures by defined factors. Cell. 2006; 126(4):663-76. [PubMed: 16904174]

65. Wang Z, Wang L, Su X, Pu J, Jiang M, He B. Rational transplant timing and dose of mesenchymal stromal cells in patients with acute myocardial infarction: a meta-analysis of randomized controlled trials. Stem cell research \& therapy. 2017; 8(1):21. [PubMed: 28129790]

66. Wei X, Yang X, Han ZP, Qu FF, Shao L, Shi YF. Mesenchymal stem cells: a new trend for cell therapy. Acta pharmacologica Sinica. 2013; 34(6):747-54. [PubMed: 23736003]

67. Noiseux N, Gnecchi M, Lopez-Ilasaca M, Zhang L, Solomon SD, Deb A, et al. Mesenchymal stem cells overexpressing Akt dramatically repair infarcted myocardium and improve cardiac function despite infrequent cellular fusion or differentiation. Molecular therapy : the journal of the American Society of Gene Therapy. 2006; 14(6):840-50. [PubMed: 16965940]

68. Gnecchi M, Zhang Z, Ni A, Dzau VJ. Paracrine mechanisms in adult stem cell signaling and therapy. Circulation research. 2008; 103(11):1204-19. [PubMed: 19028920]

69. Chou SH, Lin SZ, Kuo WW, Pai P, Lin JY, Lai CH, et al. Mesenchymal stem cell insights: prospects in cardiovascular therapy. Cell transplantation. 2014; 23(4-5):513-29. [PubMed: 24816448]

70. Karantalis V, Hare JM. Use of mesenchymal stem cells for therapy of cardiac disease. Circulation research. 2015; 116(8):1413-30. [PubMed: 25858066]

71. Oh JY, Kim MK, Shin MS, Lee HJ, Ko JH, Wee WR, et al. The anti-inflammatory and antiangiogenic role of mesenchymal stem cells in corneal wound healing following chemical injury. Stem cells (Dayton, Ohio). 2008; 26(4):1047-55.

72. Lee RH, Pulin AA, Seo MJ, Kota DJ, Ylostalo J, Larson BL, et al. Intravenous hMSCs improve myocardial infarction in mice because cells embolized in lung are activated to secrete the antiinflammatory protein TSG-6. Cell stem cell. 2009; 5(1):54-63. [PubMed: 19570514]

73. Forte A, Finicelli M, Mattia M, Berrino L, Rossi F, De Feo M, et al. Mesenchymal stem cells effectively reduce surgically induced stenosis in rat carotids. Journal of cellular physiology. 2008; 217(3):789-99. [PubMed: 18690654] 
74. Chen L, Tredget EE, Wu PY, Wu Y. Paracrine factors of mesenchymal stem cells recruit macrophages and endothelial lineage cells and enhance wound healing. PloS one. 2008; 3(4):e1886. [PubMed: 18382669]

75. Khan M, Nickoloff E, Abramova T, Johnson J, Verma SK, Krishnamurthy P, et al. Embryonic stem cell-derived exosomes promote endogenous repair mechanisms and enhance cardiac function following myocardial infarction. Circulation research. 2015; 117(1):52-64. [PubMed: 25904597]

76. Barile L, Lionetti V, Cervio E, Matteucci M, Gherghiceanu M, Popescu LM, et al. Extracellular vesicles from human cardiac progenitor cells inhibit cardiomyocyte apoptosis and improve cardiac function after myocardial infarction. Cardiovascular research. 2014; 103(4):530-41. [PubMed: 25016614]

77. Singla DK. Stem cells and exosomes in cardiac repair. Current opinion in pharmacology. 2016; 27:19-23. [PubMed: 26848944]

78. Lyu L, Wang H, Li B, Qin Q, Qi L, Nagarkatti M, et al. A critical role of cardiac fibroblast-derived exosomes in activating renin angiotensin system in cardiomyocytes. Journal of molecular and cellular cardiology. 2015; 89(Pt B):268-79. [PubMed: 26497614]

79. Cervio E, Barile L, Moccetti T, Vassalli G. Exosomes for Intramyocardial Intercellular Communication. Stem cells international. 2015; 2015:482171. [PubMed: 26089917]

80. Zhou R, Chen KK, Zhang J, Xiao B, Huang Z, Ju C, et al. The decade of exosomal long RNA species: an emerging cancer antagonist. Mol Cancer. 2018; 17(1):75. [PubMed: 29558960]

81. Chang W, Lee CY, Park JH, Park MS, Maeng LS, Yoon CS, et al. Survival of hypoxic human mesenchymal stem cells is enhanced by a positive feedback loop involving miR-210 and hypoxiainducible factor 1. Journal of veterinary science. 2013; 14(1):69-76. [PubMed: 23388440]

82. Chang W, Kim R, Park SI, Jung YJ, Ham O, Lee J, et al. Enhanced Healing of Rat Calvarial Bone Defects with Hypoxic Conditioned Medium from Mesenchymal Stem Cells through Increased Endogenous Stem Cell Migration via Regulation of ICAM-1 Targeted-microRNA-221. Molecules and cells. 2015; 38(7):643-50. [PubMed: 26062554]

83. Sadek H, Hannack B, Choe E, Wang J, Latif S, Garry MG, et al. Cardiogenic small molecules that enhance myocardial repair by stem cells. Proceedings of the National Academy of Sciences of the United States of America. 2008; 105(16):6063-8. [PubMed: 18420817]

84. Prathipati P, Nandi SS, Mishra PK. Stem Cell-Derived Exosomes, Autophagy, Extracellular Matrix Turnover, and miRNAs in Cardiac Regeneration during Stem Cell Therapy. Stem cell reviews. 2017; 13(1):79-91. [PubMed: 27807762]

85. Nollet E, Hoymans VY, Van Craenenbroeck AH, Vrints CJ, Van Craenenbroeck EM. Improving stem cell therapy in cardiovascular diseases: the potential role of microRNA. American journal of physiology Heart and circulatory physiology. 2016; 311(1):H207-18. [PubMed: 27208159]

86. Marquis-Gravel G, Stevens LM, Mansour S, Avram R, Noiseux N. Stem cell therapy for the treatment of nonischemic cardiomyopathy: a systematic review of the literature and meta-analysis of randomized controlled trials. Canadian Journal of Cardiology. 2014; 30(11):1378-84. [PubMed: 25138483]

87. Stehlik J, Edwards LB, Kucheryavaya AY, Benden C, Christie JD, Dobbels F, et al. The Registry of the International Society for Heart and Lung Transplantation: Twenty-eighth Adult Heart Transplant Report--2011. Journal of Heart \& Lung Transplantation the Official Publication of the International Society for Heart Transplantation. 2011; 30(10):1078.

88. Fischerrasokat U, Assmus B, Seeger FH, Honold J, Leistner D, Fichtlscherer S, et al. A Pilot Trial to Assess Potential Effects of Selective Intracoronary Bone Marrow-Derived Progenitor Cell Infusion in Patients With Nonischemic Dilated Cardiomyopathy. Circulation Heart Failure. 2009; 2(5):417. [PubMed: 19808371]

89. Seth S, Bhargava B, Narang R, Ray R, Mohanty S, Gulati G, et al. The ABCD (Autologous Bone Marrow Cells in Dilated Cardiomyopathy) Trial : A Long-Term Follow-Up Study. Journal of the American College of Cardiology. 2010; 55(15):1643-4. [PubMed: 20378086]

90. Vrtovec B, Poglajen G, Sever M, Lezaic L, Domanovic D, Cernelc P, et al. Effects of Intracoronary Stem Cell Transplantation in Patients With Dilated Cardiomyopathy. Journal of Cardiac Failure. 2011; 17(4):272. [PubMed: 21440864] 
91. Vrtovec B, Poglajen G, Lezaic L, Sever M, Domanovic D, Cernelc P, et al. Effects of Intracoronary CD34+ Stem Cell Transplantation in Nonischemic Dilated Cardiomyopathy Patients 5-Year Follow-Up. Circulation Research. 2013; 112(1):165. [PubMed: 23065358]

92. Sant'Anna RT, Fracasso J, Valle FH, Castro I, Nardi NB, Sant'Anna JRM, et al. Direct intramyocardial transthoracic transplantation of bone marrow mononuclear cells for non-ischemic dilated cardiomyopathy: INTRACELL, a prospective randomized controlled trial. Revista Brasileira De Cirurgia Cardiovascular Órgão Oficial Da Sociedade Brasileira De Cirurgia Cardiovascular. 2014; 29(3):437-47. [PubMed: 25372920]

93. Martino, Helena; Brofman, Paulo; Greco, Oswaldo; Bueno, Ronaldo; Bodanese, Luiz; Clausell, Nadine; , et al. Multicentre, randomized, double-blind trial of intracoronary autologous mononuclear bone marrow cell injection in non-ischaemic dilated cardiomyopathy (the dilated cardiomyopathy arm of the MiHeart study). European Heart Journal. 2015; 36(42):2898. [PubMed: 26392433]

94. Lu Y, Wang Y, Lin M, Zhou J, Wang Z, Jiang M, et al. A systematic review of randomised controlled trials examining the therapeutic effects of adult bone marrow-derived stem cells for non-ischaemic dilated cardiomyopathy. Stem Cell Research \& Therapy. 2016; 7(1):186. [PubMed: 27938412]

95. Maron BJ. Hypertrophic Cardiomyopathy: A Systematic Review. Jama. 2002; 287(10):1308. [PubMed: 11886323]

96. Maron BJ, Maron MS, Semsarian C. Genetics of Hypertrophic Cardiomyopathy After 20 Years : Clinical Perspectives. Journal of the American College of Cardiology. 2012; 60(8):705-15. [PubMed: 22796258]

97. Han L, Li Y, Tchao J, Kaplan AD, Lin B, Li Y, et al. Study familial hypertrophic cardiomyopathy using patient-specific induced pluripotent stem cells. Cardiovascular Research. 2014; 104(2):25869. [PubMed: 25209314]

98. Suzuki K, Murtuza B, Beauchamp JR, Brand NJ, Barton PJ, Varela-Carver A, et al. Role of interleukin-1beta in acute inflammation and graft death after cell transplantation to the heart. Circulation. 2004; 110(11 Suppl 1):Ii219-24. [PubMed: 15364866]

99. Narita T, Suzuki K. Bone marrow-derived mesenchymal stem cells for the treatment of heart failure. Heart failure reviews. 2015; 20(1):53-68. [PubMed: 24862087]

100. Lai RC, Chen TS, Lim SK. Mesenchymal stem cell exosome: a novel stem cell-based therapy for cardiovascular disease. Regenerative medicine. 2011; 6(4):481-92. [PubMed: 21749206]

101. Giraud MN, Guex AG, Tevaearai HT. Cell therapies for heart function recovery: focus on myocardial tissue engineering and nanotechnologies. Cardiology research and practice. 2012; 2012:971614. [PubMed: 22577591]

102. Bai Y, Sun T, Ye P. Age, gender and diabetic status are associated with effects of bone marrow cell therapy on recovery of left ventricular function after acute myocardial infarction: a systematic review and meta-analysis. Ageing research reviews. 2010; 9(4):418-23. [PubMed: 20471500] 

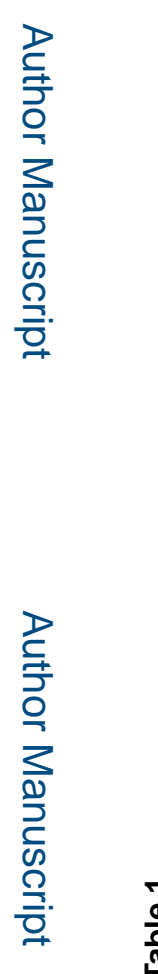

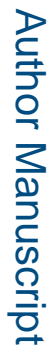

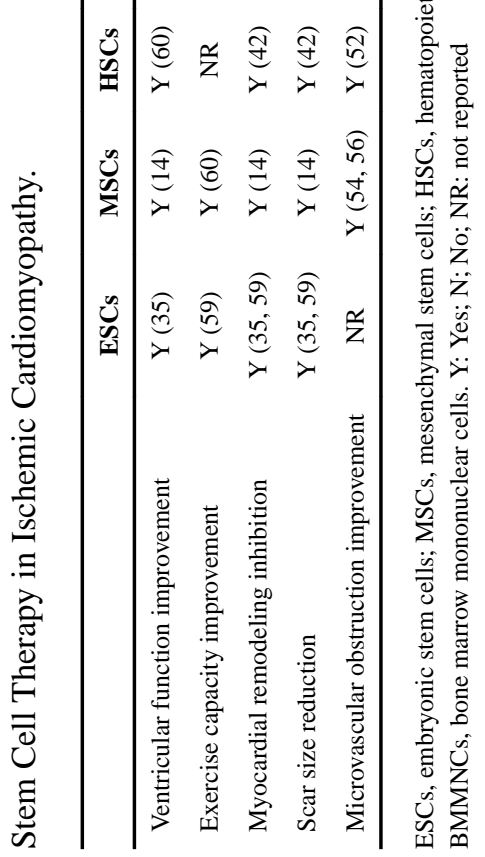

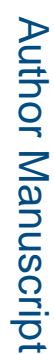

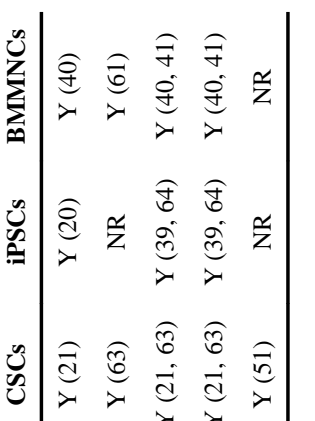

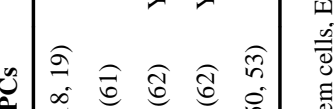

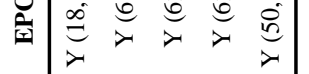

疍 